\title{
Fuzzy Model Based Surface Roughness Prediction of Fine Turning
}

\section{Edit Tóth-Laufer}

Associate Professor

Óbuda University Donát Bánki Faculty of Mechanical and Safety Engineering

Hungary

\section{Richárd Horváth}

Assistant Professor Óbuda University Donát Bánki Faculty of Mechanical and Safety Engineering

Hungary
The quality and accuracy requirements of machined parts (e.g. geometric, and shape tolerances...) continue to grow even today. These requirements include, as an important criterion, the machined surface roughness. During machining the surface roughness depends largely on the cutting parameters (cutting speed, feed, depth of cut). The authors implemented a fuzzy-based predictive model based on the available measurement data, which is able to estimate the roughness parameters belonging to the different settings. The main advantage of the fuzzy approach is that the model can be constructed on the basis of relatively few measurements as the expert knowledge can be built into the system through the rule base. Consequently, the unnecessary, time consuming measurements can be eliminated. The study discusses die-cast (eutectic) aluminum alloy part, typically used in mass production, fine-turned by a diamond tool.

Keywords: fine turning, aluminum, surface roughness, fuzzy-based model

\section{INTRODUCTION}

The surface roughness, as quality characteristics, is a particularly important criterion in the case of fine turning and finishing operations. It depends on the cutting parameters (Figure 1).

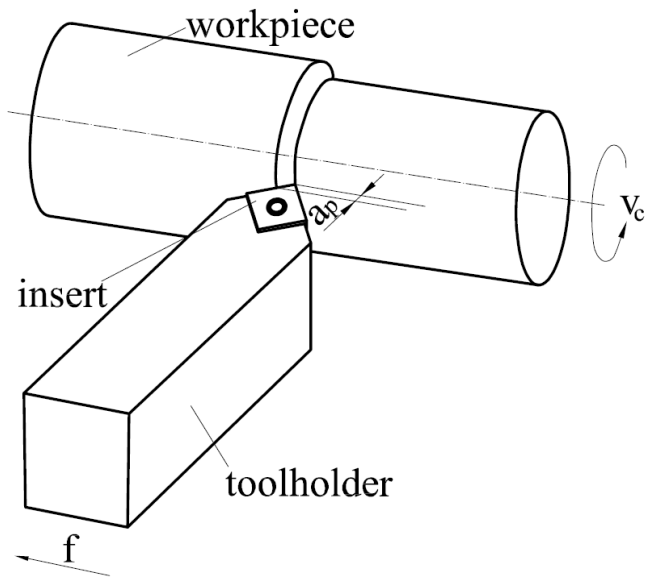

Figure 1. Schematic diagram of the turning

In technology design the desired (manufactured) roughness should be taken into account. Recent years have seen many researchers dealing with the installation of predictive models, due to the increased number of the applied materials and the modern tool materials. These models create a connection between the cutting parameters and the surface roughness.

Oğuz Çolak [1] Ti6Al4V investigated the machinability under conventional and high-pressure heating conditions. During the investigation CNMG0812 (Ti,Al)N+TiN coated insert was used and

Received: February 2016, Accepted: March 2016

Correspondence to: Richárd Horváth

Óbuda University Donát Bánki Faculty of Mechanical

and Safety Engineering, Budapest, Hungary,

E-mail: horvath.richard@bgk.uni-obuda.hu

doi:10.5937/fmet1701181T

(C) Faculty of Mechanical Engineering, Belgrade. All rights reserved the experiments were based on Taguchi L9. The cutting speed, feed, and cooling was investigated in three level $\left(v_{c}=50-70-90 \mathrm{~m} / \mathrm{min}, f=0.1-0.15-0.2 \mathrm{~mm}\right.$, cooling $=6$ 150-300 bar), while the depth of cut was held at a constant value $\left(a_{p}=2 \mathrm{~mm}\right)$. He installed an empirical model to predict $R a$ (power input, $\mathrm{kW}$ and chip removal rate, $\mathrm{cm}^{3} / \mathrm{min}$ ), based on the cutting speed, feed, depth of cut, and the cooling as input parameters. Additionally, optimal cutting parameters were defined for all three levels of cooling.

Hard turning investigation was carried out by Hamdi Aouici et al [2]. They turned material AISI H11, with hardness 40-45-50 HRC. They used tool CBN7020, whose material is $57 \% \mathrm{CBN}$ and $35 \% \mathrm{Ti}(\mathrm{C}, \mathrm{N})$. A design of the experiment was carried out, in which the cutting speed, feed, and depth of cut were changed in three levels $\left(v_{c}=120-180-240 \mathrm{~m} / \mathrm{min}, f=0.08-0.12-0.16 \mathrm{~mm}, a_{p}=0.15-\right.$ 0.3-0.45 mm). In the study empirical equations were constructed to predict e.g. the average surface roughness (Ra) and the three components of cutting force, which included the cutting parameters and the hardness of work piece. Additionally, optimal parameters were determined, while the surface roughness and the components of the cutting force were minimized.

Catalin Fetecau and Felicia Stan [3] tested the cutting ability of two kinds of polytetrafluoroethylene (PTFE) using PCD (polycrystalline diamond) tool. In plan $L_{27}$ Taguchi they changed the cutting parameters and the nose radius of the tool in three levels $\left(v_{c}=51.02\right.$ $128.58-163.28 \mathrm{~m} / \mathrm{min} ; f=0.053-0.167-0.25 \mathrm{~mm} ; a_{p}=0.5$ 1.5-2, $\left.r_{\varepsilon}=0.4-0.8-1.2 \mathrm{~mm}\right)$. As a result they created equations to predict the surface roughness for both materials, in which the cutting parameters are the inputs.

Cutting ability of engineering plastic was also examined by Lazarević et al [4]. Their researches focused on modeless optimization approach for minimization of cutting force in polyamide turning process. They examined the influence of cutting parameters $\left(v_{c}=65.03,115.61,213.88 \mathrm{~m} / \mathrm{min} ; f=0.049\right.$, 
0.098, $0.196 \mathrm{~mm} ; a_{p}=1,2,4 \mathrm{~mm} ; r_{\varepsilon}=0.4,0.8 \mathrm{~mm}$ ), on main cutting force was analyzed on the basis of the standard $L_{27}$ Taguchi's orthogonal array. In their work optimal turning parameters were determined considering Taguchi's robust design methodology.

The cutting ability of two kinds of stainless steel was examined by Selvaraj et al. [5] in dry conditions. In the study they used a TiC and TiCN coated tool (insert code: SNMG 120408 MT TT5100). The cutting speed and the depth of cut was changed in three levels $\left(v_{c}=80\right.$ $100-120 \mathrm{~m} / \mathrm{min}, f=0.04-0.08-0.12 \mathrm{~mm}$ ), while the feed was held at constant values $a_{p}=0.5 \mathrm{~mm}$ ). They have concluded that the minimum roughness in the case of both materials can be reached with $100 \mathrm{~m} / \mathrm{min}$ cutting speed and $0.04 \mathrm{~mm}$ feed, furthermore, they have found that the feed affects the surface roughness to a greater extent than the cutting speed.

Iacob et al. [6] investigated the cutting torque at the drilling of stainless steel (x22CrMoV12-1). The cutting conditions during the experiments are given below: the cutting tool: HS6-5-2C high-speed steel drill with the hardness $62 \mathrm{HRC}$ and the diameters: Ø8, Ø10, Ø12, Ø16; cutting parameters: $f=0.08-0.125 \mathrm{~mm}, n=355-7101 / \mathrm{min}$; the cooling and lubricating fluid: P 20\% emulsion. They created an equation to estimate the torque of drilling.

Barzani et al. [7] examined the cutting ability of diecast alloy $\mathrm{Al}-\mathrm{Si}-\mathrm{Cu}-\mathrm{Fe}$ for four kinds of materials: normal, Bismuth-reinforced (Bi), Strontium-reinforced (Sr), and Antimon-reinforced (Sb). In the study a TiN coated tool was used (insert code: VBGT110302F). The cutting speed and the feed were changed in three levels $\left(v_{c}=70-130-250 \mathrm{~m} / \mathrm{min} ; f=0.05-0.01-0.15 \mathrm{~mm}\right)$, while the depth of cut was held at a constant value $\left(a_{p}=0.5\right.$ $\mathrm{mm})$. They performed a design of experiments in 36 measuring points, and they have defined the membership functions of the input and the measured output (surface roughness) parameters. Based on these results they have constructed a predictive model using fuzzy approach to estimate the surface roughness.

The surface roughness minimization was carried out using fuzzy approach by Gok [8] for nodular cast iron. The so-called $\mathrm{L}_{16}\left(3^{4}\right)$ Taguchi plan was used to define the experimental run, in which the three input cutting parameters were changed in four levels $\left(v_{c}=50-100-150\right.$ $200 \mathrm{~m} / \mathrm{min} ; f=0.05-0.075-0.01-0.125 \mathrm{~mm} ; a_{p}=0.5-1-$ 1.5-2 mm).

Olteanu et. al examined 42CrMo4 steel milling [9] using the neural network. The aim was to analyze the influence of cutting parameters (feed and cutting speed) respectively on the cutting torques, respectively. The used cutting tool was a milling cutter type R365080Q27-S15M of $80 \mathrm{~mm}$ diameter, with insert, whose approach angle was $65^{\circ}$. They used a 9257B Kistler dynamometer for measuring the forces and torques during milling. The used parameters were the feed $\left(f_{z}=\right.$ 0.05-0.075-0.1-0.125-0.15 mm/tooth), and the cutting speed $\left(v_{c}=125.66-150.8-163.36-170.93-201.06 \mathrm{~m} / \mathrm{min}\right)$, while the depth of cut $a_{p}=0.5 \mathrm{~mm}$ was constant during the tests. Finally, a model was proposed that provides a good agreement between the measured values and calculated numerical values.

The authors have already dealt with the examination of aluminum fine-turning. Using the response surface method they have implemented a predictive model, in which in addition to the input cutting parameters the tool edging material and the work piece material are also be used in the equations as a quality variable [10, $11,12]$. They showed for different edge geometry tools that the statistical parameters of the surface roughness depend on the edge geometry [13].

Furthermore, they designed a fuzzy-based model, which can assign a goodness value to the different cutting parameter settings taking into account the surface roughness and also the productivity. The goodness factor allows the ranking of the different settings, consequently, the most appropriate values (cutting speed, feed, and depth of cut) can be selected [14].

\section{MATERIAL AND METHOD}

\subsection{Tools used in the experiments}

In the study die-cast aluminum parts were used. The composition of the eutectic material (AS12) is the following: $\mathrm{Al}=88.43 \%, \mathrm{Si}=11.57 \%$, the hardness of the work piece: $64 \pm 2 \mathrm{HB}_{2.5 / 62.5 / 30}$.

The modification of aluminium alloys is also highly important research area. Modification and material properties of similar cast alloy (Al-Si-Cu) was examined by Farkašová et al. [15].

The overall size of the available work piece is: $\varnothing 110.40 \mathrm{~mm}$. The surface roughness values were measured using Mitutoyo SJ-301 roughness tester in the experimental run twelve times (at $30^{\circ}$ ).

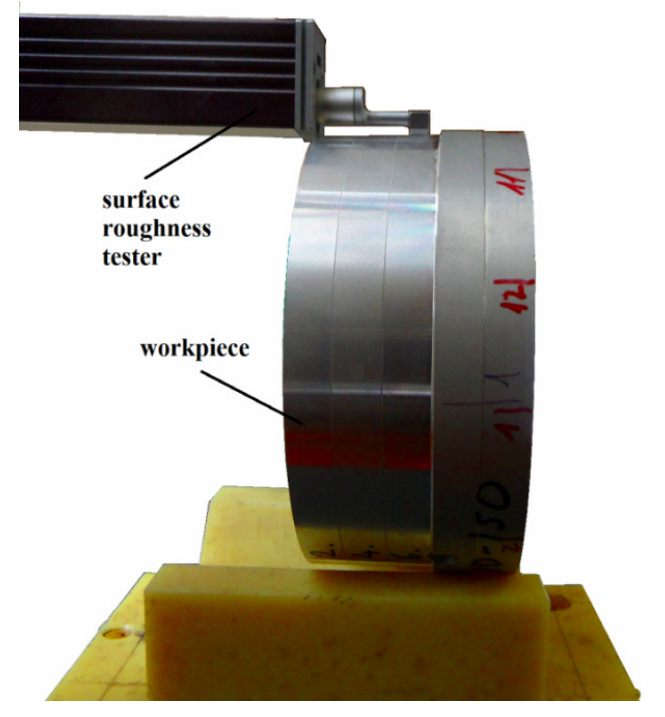

Figure 2. The measurement of surface roughness

The tool code used in the experiment: DCGW 11T304, edge geometry: ISO, edge material: PCD (polycrystalline diamond). The specification of the toolholder: SDJCR 1616H 11.

The examinations were performed using NCT euroturn $12 \mathrm{~b} \mathrm{CNC}$ turning machine (maximum spindle speed $=60001 / \mathrm{min}$, power $=7 \mathrm{~kW})$.

\subsection{Measured parameters}

In the study the surface roughness characteristics most commonly used by the industry were defined ( $R a-$ average surface roughness, $R z$ surface height). 


\section{a. Average surface roughness (Ra)}

The average surface roughness is one of the most commonly used height direction feature, because it is easy to measure and based on the change in its value broad conclusions can be drawn with regards to both the material, and the tool. When determining it, one can be constructed the arithmetic means of the absolute value distances between the real-profile points measured on the base length and the center line. (Figure 3). The mathematical definition is as follows:

$$
\begin{aligned}
& R a=\frac{1}{l} \int_{0}^{l}|y(x)| d x \\
& R a=\frac{1}{n} \sum_{i=1}^{n}\left|y_{i}\right|
\end{aligned}
$$

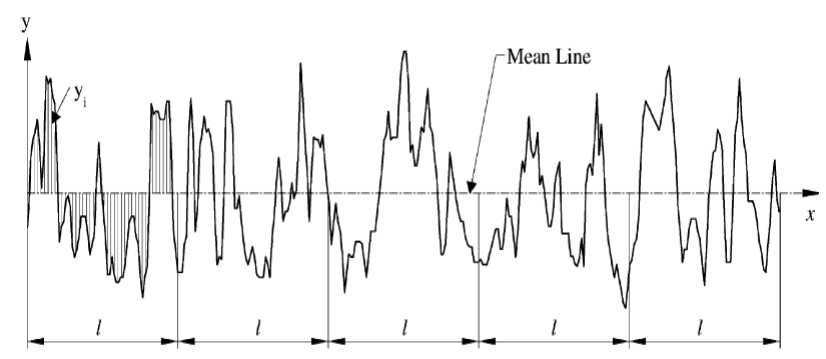

Figure 3. Average surface roughness (Ra) [16]

However, the surface roughness $R a$ is unable to differentiate between peak and valley regions. This is the justification for measuring e.g. parameter $R z$.

\section{b. Surface height $(R z)$}

The surface height can be interpreted as the average of the distances between the five maximum peaks and valleys measured on the base length profile (Figure 4). The mathematical definition is given bellow:

$$
R z_{(I S O)}=\frac{1}{n}\left(\sum_{i=1}^{n} p_{i}-\sum_{i=1}^{n} v_{i}\right)
$$

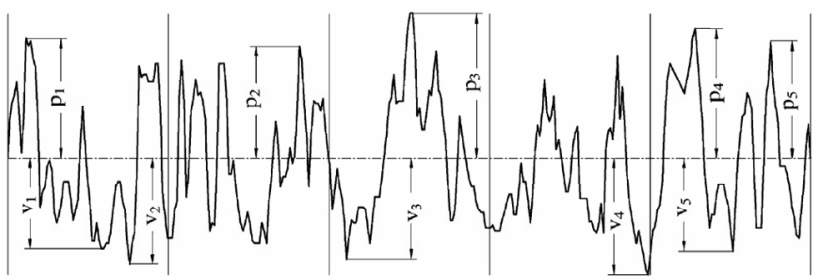

Figure 4. Surface height (Rz) [16]

\subsection{The fuzzy model}

The so-called central composite experimental design plan was used for the determination of the experimental run. The cutting parameter range has been adjusted to cover the larger fine turning range. The input cutting parameters were studied in five levels, their values are shown in Table 1.

The experimental run obtained from Table 1, and the central composite experimental design plan are illustrated in Table 2.
Table 1. Cutting parameters belonging to each level

\begin{tabular}{|l|c|c|c|}
\hline Levels & $v_{c}, \mathrm{~m} / \mathrm{min}$ & $f, \mathrm{~mm}$ & $a_{p}, \mathrm{~mm}$ \\
\hline-1.28719 & 500 & 0.05 & 0.2 \\
\hline-1 & 667 & 0.058 & 0.267 \\
\hline 0 & 1250 & 0.085 & 0.5 \\
\hline 1 & 1833 & 0.112 & 0.733 \\
\hline 1.28719 & 2000 & 0.12 & 0.8 \\
\hline
\end{tabular}

Table 2. Cutting parameter levels in the experimental run

\begin{tabular}{|c|c|c|c|}
\hline Experimental run & $v_{c}$ & $f$ & $a_{p}$ \\
\hline 1 & -1 & -1 & -1 \\
\hline 2 & -1 & -1 & 1 \\
\hline 3 & -1 & 1 & -1 \\
\hline 4 & -1 & 1 & 1 \\
\hline 5 & 1 & -1 & -1 \\
\hline 6 & 1 & -1 & 1 \\
\hline 7 & 1 & 1 & 1 \\
\hline 8 & 1 & 1 & 1 \\
\hline 9 & -1.28719 & 0 & 0 \\
\hline 10 & 1.28719 & 0 & 0 \\
\hline 11 & 0 & -1.28719 & 0 \\
\hline 12 & 0 & 1.28719 & 0 \\
\hline 13 & 0 & -1 & -1.28719 \\
\hline 14 & 0 & -1 & 1.28719 \\
\hline 15 & 0 & 0 & 0 \\
\hline 16 & 0 & 0 & 0 \\
\hline
\end{tabular}

\subsection{The fuzzy model}

The fuzzy approach was introduced by L. A. Zadeh, who constructed a novel method in 1965 to describe the previously mathematically indescribably linguistic concepts [17]. The fuzzy based systems are able to handle the uncertainty, imprecision, and subjectivity in the data as well as in the evaluation process. In this way they serve a more realistic result. These kinds of models can be advantageously used in the cases when there is not enough data to construct the statistical model, or the causal relationship is not precise enough. Consequently, it is a commonly used method in predictive models [18].

The advantages described above can be exploited in order to predict the roughness parameters, because carrying out the measurements for all possible combinations of the settings (cutting speed, feed, and depth of cut) is a cost- and time-consuming task. Therefore, in practice this is not carried out. Instead of this method a predictive model can be applied, which can estimate the surface roughness parameters based on some characteristic measurement data. For this purpose, the authors have developed a fuzzy based model, which takes into account the appropriately chosen cutting parameters and the expert knowledge was built into the system through the rule base.

In the fuzzy model Mamdani-type inference is used [19]. The inputs are the cutting speed $\left(v_{c}\right)$, the feed $(f)$, and the depth of cut $\left(a_{p}\right)$, the outputs are the predicted values: the average surface roughness $(R a)$, and the surface height $(R z)$. The evaluation is performed based on the rule base as represented by the expert knowledge.

The general structure of the rules can be defined as follows:

IF $\mathrm{x}_{1}$ is $A_{1, i_{1}}$ and $\ldots$ and $\mathrm{x}_{\mathrm{n}}=A_{n, i_{n}}$ THEN y $=Y_{i_{1}, \ldots i_{n}}$. 
where $A_{k, i_{k}}$ is the antecedent set $i_{k}$ belongs to input k, $Y_{i_{1}, \ldots j_{n}}$ is the consequent part of the rule, $i_{j}=1 . . n_{j}$, and $n_{j}$ is the number of the antecedent sets belonging to input $\mathrm{j}$. The rule premises are formed as all the all possible combinations of the antecedent sets. The steps of the evaluation are illustrated in Figure 5, the applied rule base is shown in Table 3, while the detailed evaluation steps are described in the following section.

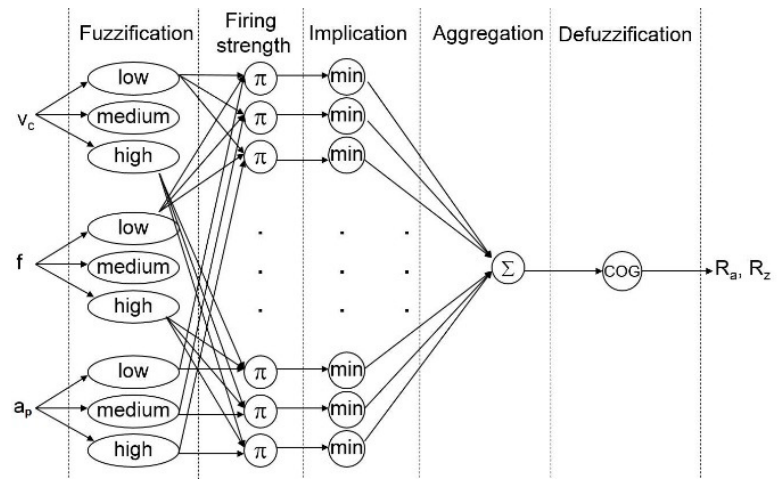

Figure 5. Steps of the fuzzy evaluation

Table 3. The applied rule base

\begin{tabular}{|c|c|c|c|c|}
\hline \multicolumn{3}{|c|}{ Inputs } & \multicolumn{2}{c|}{ Outputs } \\
\hline$v_{c}$ & $f$ & $a$ & $R a$ & $R z$ \\
\hline low & low & low & excellent & excellent \\
\hline low & low & medium & excellent & excellent \\
\hline low & low & high & excellent & excellent \\
\hline low & medium & low & excellent & good \\
\hline low & medium & medium & good & good \\
\hline low & medium & high & good & good \\
\hline low & high & low & medium & medium \\
\hline low & high & medium & bad & medium \\
\hline low & high & high & medium & bad \\
\hline medium & low & low & excellent & excellent \\
\hline medium & low & medium & excellent & excellent \\
\hline medium & low & high & good & good \\
\hline medium & medium & low & medium & medium \\
\hline medium & medium & medium & good & medium \\
\hline medium & medium & high & good & medium \\
\hline medium & high & low & good & bad \\
\hline medium & high & medium & bad & bad \\
\hline medium & high & high & bad & bad \\
\hline high & low & low & excellent & good \\
\hline high & low & medium & excellent & good \\
\hline high & low & high & good & good \\
\hline high & medium & low & good & good \\
\hline high & medium & medium & good & good \\
\hline high & medium & high & good & medium \\
\hline high & high & low & good & good \\
\hline high & high & medium & good & medium \\
\hline high & high & high & good & excellent \\
\hline
\end{tabular}

The first step of the evaluation is the fuzzification, when a membership value is assigned to the input value. This assignment is performed using a membership function, which is the generalization of the characteristic function, but in this case the result is not that whether or not the value belongs to the set. In the case of the fuzzy membership function the belonging of the set rate can be defined. In the authors' predictive model three different sets (low, medium, high) belong to each input parameter. Accordingly, in the first step of the evaluation it can be decided to what extent the current value can be considered as low, medium, or high. In this step trapezoidal membership function is applied, which can be defined as follows:

$$
\mu_{A_{k_{k}}}(x)=\left\{\begin{array}{cc}
0 & x \leq a_{i_{k}} \\
\frac{x-a_{i_{k}}}{b_{i_{k}}-a_{i_{k}}} & a_{i_{k}} \leq x \leq b_{i_{k}} \\
1 & b_{i_{k}} \leq x \leq c_{i_{k}} \\
\frac{d_{i_{k}}-x}{d_{i_{k}}-c_{i_{k}}} & c_{i_{k}} \leq x \leq d_{i_{k}} \\
0 & d_{i_{k}} \leq x
\end{array}\right.
$$

where $a_{i_{k}}, b_{i_{k}}, c_{i_{k}}$, and $d_{i_{k}}$ are the membership function parameters, i.e. they define breakpoints of the function.

The membership functions belonging to each input are shown in Figures. 6-8.

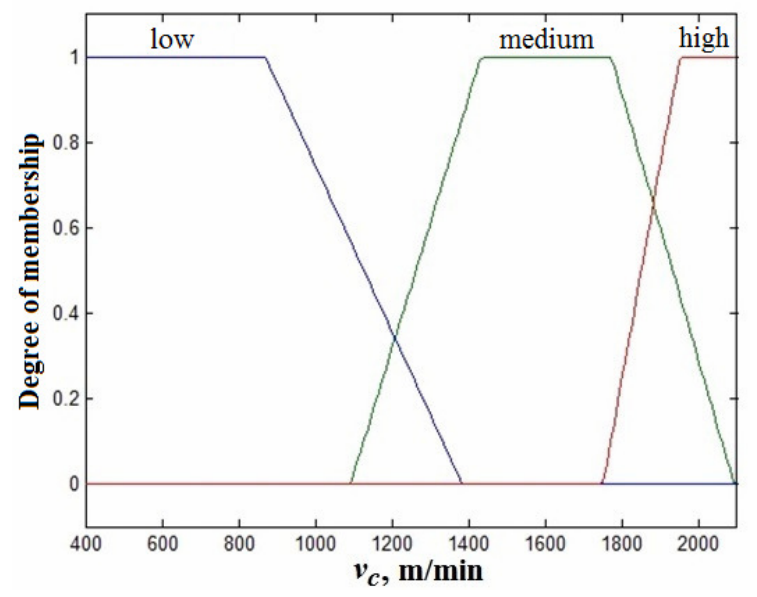

Figures 6. Membership functions of the cutting speed

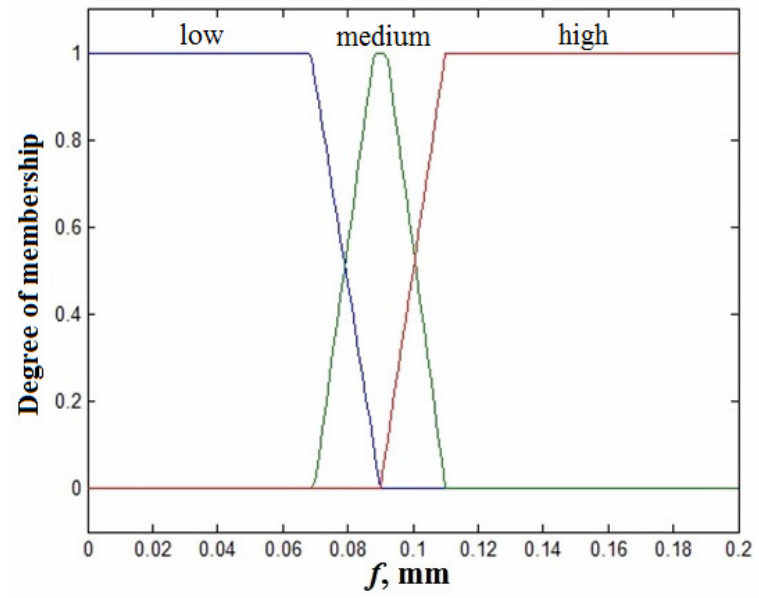

Figures 7. Membership functions of the feed

In the second step of the evaluation the obtained fuzzified values are linked by a conjunction operator to define their combined effect. This linking form is the basis of the rule premise value as it is shown in Table 3, and its result is the so-called firing strength $\left(w_{i}\right)$. In the model the product operator was used:

$$
\mathrm{w}_{\mathrm{i}}=\mu_{\mathrm{A}_{\mathrm{kik}_{\mathrm{k}}}}\left(\mathrm{v}_{\mathrm{c}}\right) \mu_{\mathrm{B}_{\mathrm{kjk}}}(\mathrm{f}) \mu_{\mathrm{C}_{\mathrm{k}_{\mathrm{k}}}}(\mathrm{a})
$$

where $\mu_{A_{k_{k}}}\left(v_{c}\right), \mu_{B_{k_{j k}}}(f)$, and $\mu_{C_{k_{k}}}(a)$ are the membership values of $v_{c}, f, a$, respectively. 


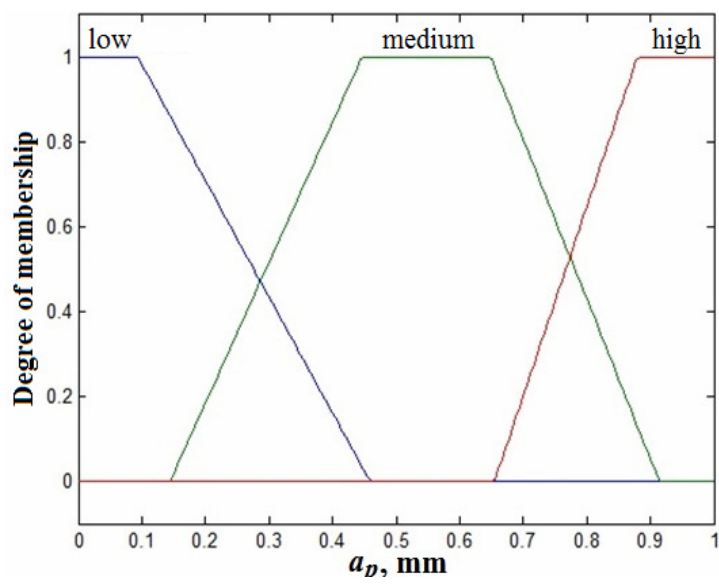

Figures 8. Membership functions of the depth of cut

The next operation is the implication, whose result represents the participation rate of the current rule in the overall conclusion. This result is obtained from the linking of the firing strength and the consequent set by an appropriately chosen operator. In this case the minimum operator was used:

$$
y_{Y_{i}}=\min \left(w_{i}, \mu_{Y_{i}}\right)
$$

where $w_{i}$ is the firing strength belonging to rule I and $\mu_{Y i}$ is the consequent set belonging to rule $i$. For the representation the consequent sets belonging to the roughness parameters the Gauss-type membership functions were used, which can be defined by (8), the specific sets belonging to the outputs are illustrated in Figures. 9-10. The consequent set value assigned to each rule are presented in Table 3.

$$
\mu_{B_{i}}(y)=e^{-\frac{(x-m)^{2}}{2 \sigma^{2}}}
$$

where $m$ is the mean, $\sigma$ is a measure of the width of the curve.

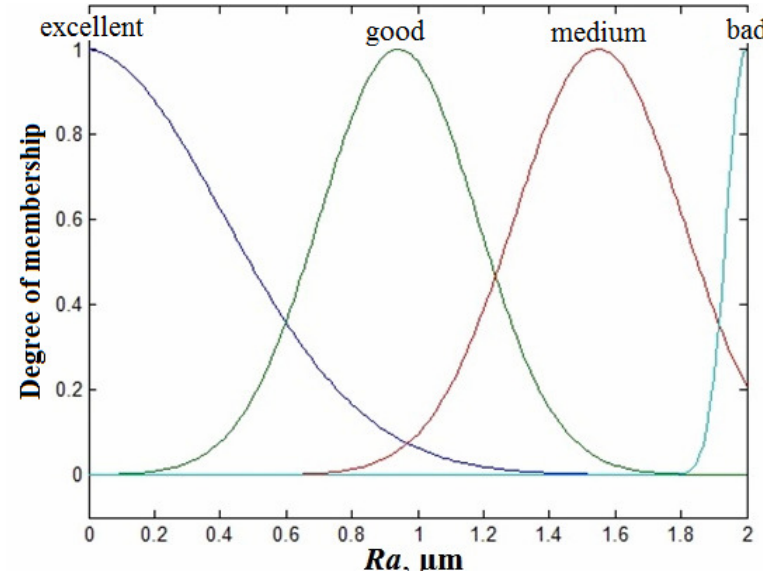

Figures 9. The consequent sets belong to the average surface roughness

In the next step, the consequent sets obtained per rules should be aggregated to determine the overall system output, which can be defined in the model as the weighted average of the consequent sets.

$$
y=\sum_{i=1}^{n} w_{i} y_{Y_{i}} / \sum_{i=1}^{n} w_{i}
$$

where $w_{i}$ is the firing strength belongs to rule $\mathrm{i}, y_{Y_{i}}$ is the consequent belonging to rule $i$, and $n$ is the number of the rules.

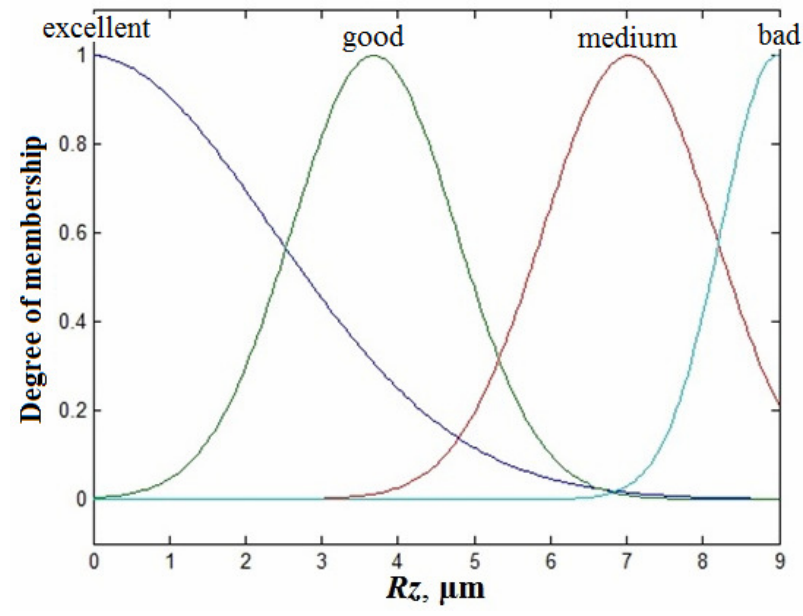

Figures 10. Consequent sets belong to the surface height

The result of the aggregation can be a complex shaped set, therefore, for easy legibility and usability, it should be defuzzified. In this step a crisp value is assigned to the set, which best represents the obtained set. The applied method is the center of gravity:

$$
y_{\text {out }}=\frac{\int_{y \in \mu_{Y}} \mu_{Y}(y) y d y}{\int_{y \in \mu_{Y}} \mu_{Y}(y) d y}
$$

where $\mu_{\mathrm{Y}}$ is the rule consequent.

\section{RESULTS}

The predictive model was implemented in Matlab Fuzzy Logic Toolbox environment, and the obtained predicted values are compared to the measured values. The results show that in the case of both parameters ( $\mathrm{Ra}$ and $\mathrm{Rz}$ ) the measured and predicted values are very close to each other (Figure 11).

Determining the difference between the measured and predicted values in each measuring point:

$$
\begin{aligned}
\Delta \mathrm{Ra} & =\mathrm{Ra}_{\text {measured }}-\mathrm{Ra}_{\text {estimated }} . \\
\Delta \mathrm{Rz} & =\mathrm{R} \mathrm{z}_{\text {measured }}-\mathrm{R} \mathrm{z}_{\text {estimated. }}
\end{aligned}
$$

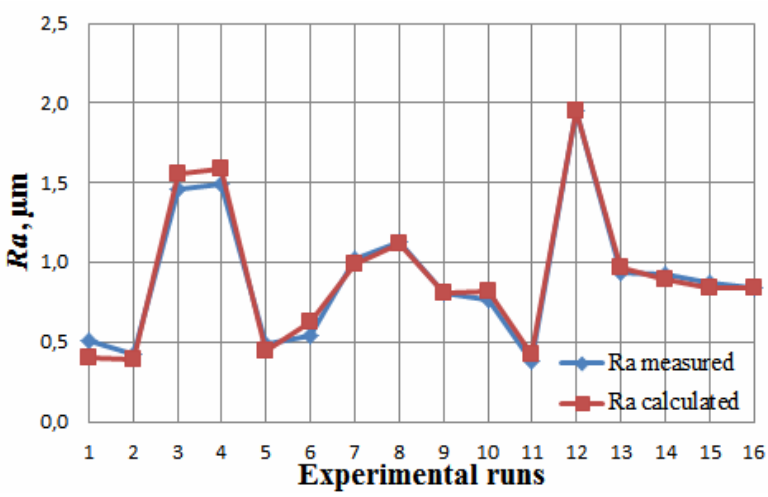

a) The measured and predicted average surface roughness values $(\mathbf{R a})$ depending on the experimental run 


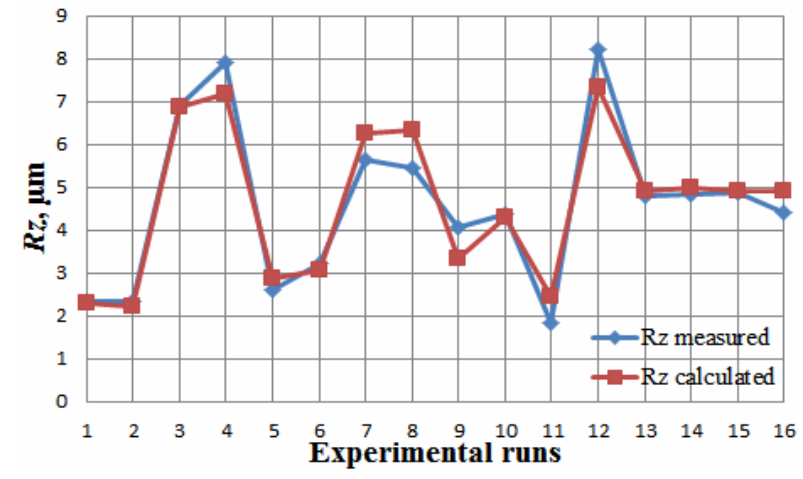

b) The measured and predicted surface height $(R z)$ depending on the experimental run

Figure 11. Comparison of the measured and predicted surface roughness parameters $R a$ and $R z$

In the case of average surface roughness $(R a)$ the value $\Delta R a$ is between $0.11 \mu \mathrm{m}$ and $-0-1 \mu \mathrm{m}$, while the surface height $(R z)$ the value $\Delta R z$ is between $-0.9 \mu \mathrm{m}$ and $0.85 \mu \mathrm{m}$. The analysis of the residuals (Figure 12) shows that the differences follow a normal distribution. The expected values of the errors are approximately zero and their dispersion in the case of $R a$ is $0.057 \mu \mathrm{m}$, while in the case of $R z$ is $0.49 \mu \mathrm{m}$.

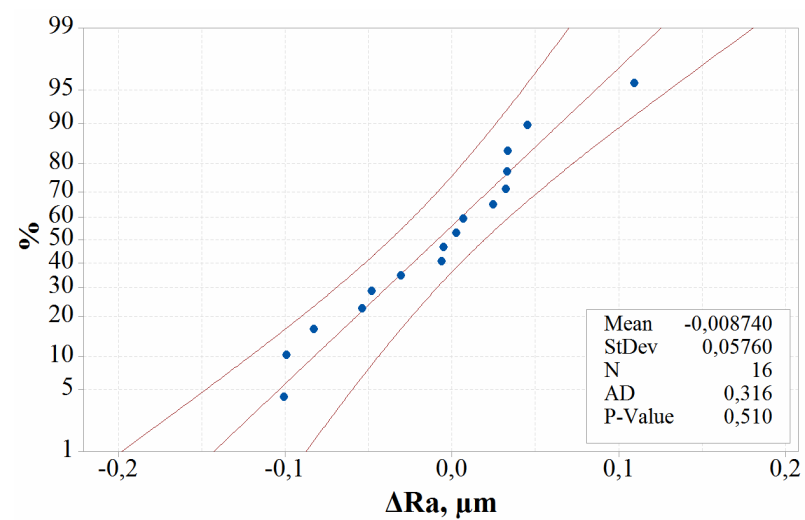

a) Average surface roughness residuals ( $\Delta R a)$ representation in normality plot

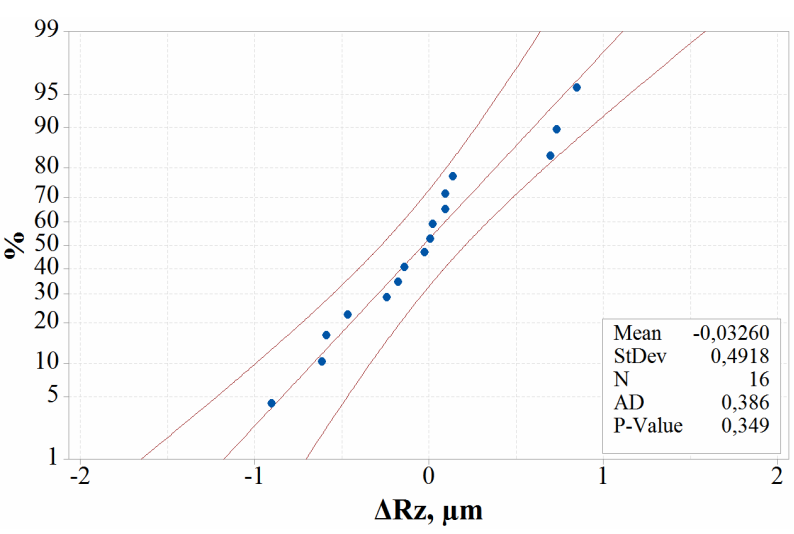

b) Surface height residuals $(\Delta R z)$ representation in normality web

Figure 12. Residuals representation in normality plot

The significance test proved that the feed has a significant effect on the roughness as it can also be seen in the main effect diagrams. Figure 13 illustrates that increasing the feed the surface roughness also increases, while the other two parameters (cutting speed, depth of cut) have no significant effect. This statement is true for both roughness parameters $(R a, R z)$. Consequently, considering the productivity, at low feed, high cutting speed is recommended.

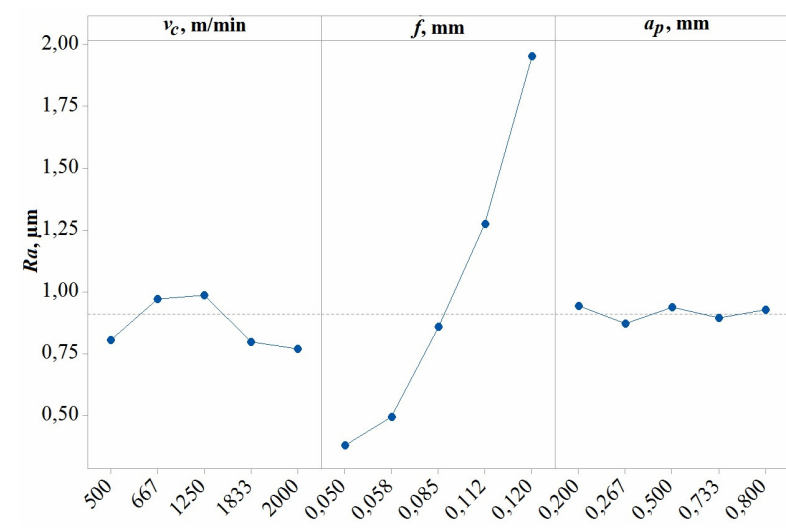

a) Main effect diagram of average surface roughness ( $\mathrm{Ra}$ )

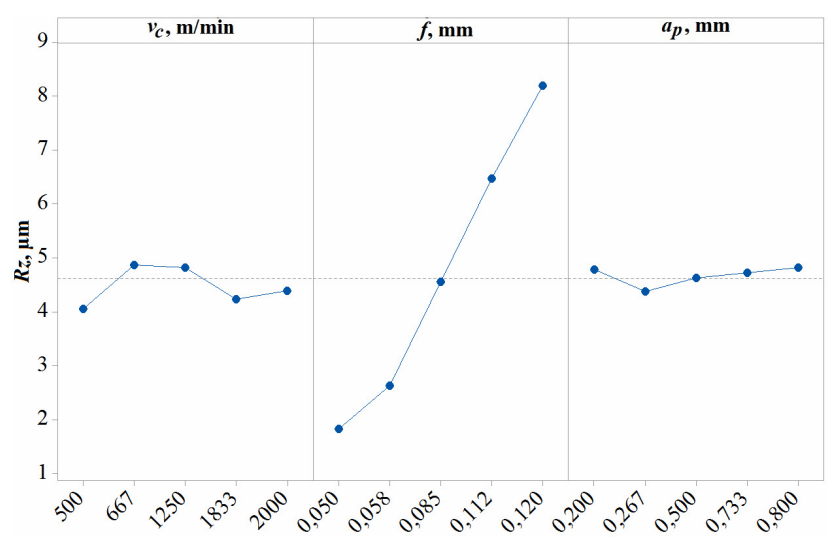

b) Main effect diagram of surface height (Rz)

Figure 13. Main effect diagrams

\section{CONCLUSIONS}

The machined surface roughness is an important criterion during fine-turning. Therefore, its prediction is essential in technological pre-planning. The cutting settings (cutting speed, feed, and depth of cut) have a significant effect on the surface roughness. In this study, the authors investigated the fine-turning of a die-cast aluminum alloy applied in eutectic mass production using a design of experiments. Since carrying out the measurements all the possible combinations of the cutting parameters would be extremely cost and timeconsuming task, there is a need to create a predictive model, which is able to substitute these measurements. The fuzzy based model is suitable for solving this problem given relatively few measurement data and incorporated the expert knowledge.

After the testing of the authors' fuzzy based predictive model, the following conclusions can be drawn:

- applying the design of experiment in cutting research is highly welcome, because the reduction of the measuring points is cost and time-consuming;

- the feed has a significant effect on the surface roughness $(R a, R z)$. By increasing the feed, the surface roughness also increases.

using a modern diamond tool in the case of eutectic the tested aluminum alloy with surface $R a<0,5 \mu \mathrm{m}$ can be manufactured by setting a low feed value; 
- taking into account the roughness minimization and the productivity, a low feed rate and the higher cutting speed is recommended;

- the suggested fuzzy method can be advantageously applied in the roughness parameter prediction model;

- compared to the measured values the result of constructed predictive fuzzy model estimates the roughness parameters with sufficient precision in technology pre-planning;

- the difference between the measured and predicted values $(\Delta R a, \Delta R z)$ shows a normal distribution, with low dispersion and zero expected value;

In this paper, the authors focused on the cut surface as an important quality parameter but in the future the research should be extended additional essential parameters, e.g.: the statistical parameters of surface roughness; cutting force parameters.

\section{REFERENCES}

[1] Çolak, O.: Optimization of Machining Performance in High-Pressure Assisted Turning of Ti6Al4V Alloy: Strojniški vestnik - Journal of Mechanical Engineering vol. 60. No. 10, pp. 675-681, 2014.

[2] Aouici, H., et al.: Analysis of surface roughness and cutting force components in hard turning with CBN tool: Prediction model and cutting conditions optimization, Measurement, 45, pp. 344-353, 2012.

[3] Fetecau, C., Stan F.: Study of cutting force and surface roughness in the turning of polytetra-fluoroethylene composites with a polycrystalline diamond tool, Measurement, 45 pp. 1367-1379, 2012.

[4] Lazarević, D., Janković, P., Madić, M., Lazarević, A.: Robust Conditions for Cutting Force Minimization in Polyamide Turning Process, FME Transactions Vol. 43, No. 2., pp- 114-118, 2015.

[5] Selvaraj, D.P., Chandramohan, P., Mohanraj M.: Optimization of surface roughness, cutting force and tool wear of nitrogen alloyed duplex stainless steel in a dry turning process using Taguchi method, Measurement, 49, pp. 205-215, 2014.

[6] Iacob, M., Vlase, A., Blăjină, O.: Calculus of the relationship of the cutting moment at drilling of the stainless steel X22CrMoV12-1, Scientific BulletinUniversity Politehnica of Bucharest Series D, Vol. 77, No. 3, pp. 145-152, 2015.

[7] Barzani, M.M., et al.: Fuzzy logic based model for predicting surface roughness of machined $\mathrm{Al}-\mathrm{Si}-$ $\mathrm{Cu}-\mathrm{Fe}$ die casting alloy using different additivesturning, Measurement, 61, pp. 150-161, 2015.

[8] Gok, A.: A new approach to minimization of the surface roughness and cutting force via fuzzy TOPSIS, multi-objective grey design and RSA, Measurement, 70 pp. 100-109, 2015.

[9] Olteanu, E.L., et al.: The milling moments prediction using a neural network model, Scientific Bulletin-University Politehnica of Bucharest Series D, Vol. 77, No. 4, pp. 141-150, 2015.

[10] Horváth, R., Drégelyi-Kiss, Á.: Analysis of surface roughness of aluminum alloys fine turned: United phenomenological models and multi-performance optimization, Measurement 65, pp. 181-192, 2015.

[11] Horváth, R., Drégelyi-Kiss, Á., Mátyási, Gy.: Application of RSM Method for the Examination of Diamond Tools, Acta Polytechnica Hungarica, Vol. 11, No. 2, pp. 137-147, 2014.

[12] Horváth, R., Drégelyi-Kiss, Á., Mátyási, Gy.: The examination of surface roughness parameters in the fine turning of Hypereutectic aluminium alloys, Scientific Bulletin-University Politehnica of Bucharest Series D, Vol. 77, No. 2, pp. 205-216, 2015.

[13] Horváth, R., Czifra, Á., Drégelyi-Kiss, Á.: Effect of conventional and non-conventional tool geometries to skewness and kurtosis of surface roughness in case of fine turning of aluminium alloys with diamond tools, International Journal of Advanced Manufacturing Technology 78 pp. 297-304, 2015.

[14] Horváth, R., Tóth-Laufer, E.: Fuzzy Model-Based Cutting Parameter Combination Optimization, $18^{\text {th }}$ International Conference on Intelligent Engineering Systems - INES 2014, Tihany, Hungary, July 3-5, pp. 151-155, 2015.

[15]Farkašová, M., Tillová, E., Chalupová, M.: Modification of Al-Si-Cu cast alloy, FME Transactions Vol. 41, No. 3., pp. 210-215, 2013.

[16] Gadelmawlaa, E.S., Kourab, M.M., Maksoucf, T.M.A., Elewaa, I.M., Solimand, H.H.: Roughness parameters, Journal of Materials Processing Technology vol. 123, pp. 133-145, 2002.

[17]Zadeh, L.A.: "Fuzzy sets," Information and Control, Vol. 8, No. 3, pp. 338-353, 1965.

[18] Bessissa, L., Boukezzi, L., Mahi, D.: A Fuzzy Logic Approach to Model and Predict HV Cable Insulation Behaviour under Thermal Aging, Acta Polytechnica Hungarica, Vol. 11, No. 3, pp. 107123, 2014.

[19] Kóczy, T.L., Tikk, D.: Fuzzy systems (in Hungarian), Typotex, 2001.

\section{NOMENCLATURE}

$\begin{array}{ll}a_{p} & \text { depth of cut, } \mathrm{mm} \\ f & \text { feed, } \mathrm{mm} \\ v_{c} & \text { cutting speed, } \mathrm{m} / \mathrm{min} \\ R a & \text { average surface roughness, } \mu \mathrm{m} \\ R z & \text { surface height, } \mu \mathrm{m} \\ \mathrm{AS} 12 & \text { die-cast eutectic aluminum alloy } \\ r_{\varepsilon} & \text { nose radius, } \mathrm{mm}\end{array}$

\section{ПРЕДВИЪАЊЕ ХРАПАВОСТИ ПОВРШИНЕ КОД ФИНОГ СТРУГАҢА НА ОСНОВУ ФАЗИ МОДЕЛА}

\section{Е. Тот-Лауфер, Р. Хорват}

Квалитет и прецизност обрађених делова (нпр. геометрија, толеранција зависна од облика ...) су захтеви који чак и данас постају све већи. Ови захтеви укључују храпавост обрађене површине као 
значајан критеријум. У току обраде храпавост површине зависи великим делом од параметара резања (брзине резања, помоћног кретања, дубине резања). Аутори су применили фази модел предвиђања користећи доступне податке мерења. Модел може да прорачуна параметре храпавости који припадају различитим условима обраде. Главна предност фази приступа је та што модел може да се конструише на основу релативно малог броја мерења, пошто стручно знање може да се угради у систем преко базе правила. Отуда, непотребна мерења која одузимају време могу да се елиминишу. У раду се разматра изливање у калупима дела од легуре алуминијума (еутектика), обично коришћеног у масовној производњи, који се обрађује дијамантским алатом методом финог стругања. 